\title{
COMPARATIVE FEEDING BEHAVIOUR OF Penaeus kerathurus (FORSKÅL, 1775) (CRUSTACEA, PENAEIDAE) AND Palaemon serratus (PENNANT, 1777) (CRUSTACEA, PALAEMONIDAE) DURING LARVAL DEVELOPMENT \\ COMPARACIÓN DEL COMPORTAMIENTO ALIMENTICIO DE Penaeus kerathurus (FORSKÅL, 1775) (CRUSTACEA, PENAEIDAE) Y Palaemon serratus (PENNANT, 1777) (CRUSTACEA, PALAEMONIDAE) DURANTE EL DESARROLLO LARVARIO.
}

\author{
L. Narciso* \\ S. Morais \\ Departamento de Zoologia e Antropologia \\ Faculdade de Ciências da Universidade de Lisboa \\ Laboratório Marítimo da Guia \\ Estrada do Guincho \\ Forte N.S. da Guia, 2750-642 \\ Cascais, Portugal \\ *E-mail: lnarciso@fc.ul.pt
}

Recibido en junio de 2001; aceptado en septiembre de 2001

\begin{abstract}
Aspects of larval feeding of two autochthonous species of shrimp, Penaeus kerathurus (Forskål, 1775) and Palaemon serratus (Pennant, 1777), were studied. For P. kerathurus, feeding rates on Chlorella sp. and Isochrysis galbana Parke were determined at 3 different concentrations, during the protozoeal stage, and on Artemia franciscana Kellog at 4 different densities, during the mysis stage. The selectivity between Brachionus plicatilis Müller and Artemia franciscana nauplii was tested experimentally and the Ivlev selectivity index was calculated at the mysis stage. For Palaemon serratus Zoea III, V and VII, feeding rates on newly hatched A. franciscana nauplii, on metanauplii enriched during 24 hours in Protein Selco ${ }^{\circledR}$ and on starved metanauplii were determined. The Ivlev selectivity index was also calculated. The results revealed that Penaeus kerathurus and Palaemon serratus larvae have a negative selectivity for $B$. plicatilis. It is also suggested that the optimal density of $A$. franciscana for the mysis stage of $P$. kerathurus is around 10 nauplii $\mathrm{mL}^{-1}$. Finally, it was shown that the use of enrichment products leading to a very high lipid content of the prey may reduce their consumption rate.
\end{abstract}

Key words: Penaeus kerathurus, Palaemon serratus, larval rearing, feeding rate, prey selectivity.

\section{RESUMEN}

Se estudiaron aspectos de la alimentación de larvas de dos especies autóctonas de camarón, Penaeus kerathurus (Forskål, 1775) y Palaemon serratus (Pennant, 1777). Se determinaron las tasas de alimentación de Penaeus kerathurus con Chlorella sp. e Isochrysis galbana Parke, en tres 
concentraciones distintas, durante el estadio de protozoea, y con Artemia franciscana Kellog, en cuatro densidades diferentes, durante el estadio misis. También se probó experimentalmente la selectividad de $P$. kerathurus entre Brachionus plicatilis Müller y nauplios de Artemia franciscana y se calculó el índice de selectividad de Ivlev, durante el estadio misis. Para Palaemon serratus en los estadios Zoea III, V y VII, se calcularon las tasas de alimentación con nauplios recién eclosionados de A. franciscana, con metanauplios enriquecidos con Protein Selco ${ }^{\circledR}$ durante 24 horas y con metanauplios sin alimentar. También se calculó el índice de selectividad de Ivlev. Los resultados revelaron que las larvas de Penaeus kerathurus y de Palaemon serratus tienen selectividad negativa hacia $B$. plicatilis. También se sugiere que la densidad óptima de $A$. franciscana para el estadio misis de $P$. kerathurus es alrededor de 10

nauplios $\mathrm{mL}^{-1}$. Finalmente, se demostró que el uso de productos de enriquecimiento que conducen a un contenido muy elevado de lípidos en las presas puede reducir la tasa de consumo.

Palabras clave: Penaeus kerathurus, Palaemon serratus, cultivo de larvas, tasa de alimentación, selectividad de presa.

\section{INTRODUCTION}

Portugal has an important tradition in crustacean consumption. The fishing industry is productive, but it is still not meeting the demand, i.e., shrimp landings are still much lower than imports. The culture of the penaeid shrimp Penaeus japonicus Bate, 1888, in intensive and semi-intensive systems in the South coast of Portugal showed an increase during the 1980s (Arrobas, 1989; Arrobas et al., 1989). Before then, the culture potential of the autochthonous species Penaeus kerathurus was investigated in Portugal (Figueiredo, 1970), Spain (Rodriguez, 1975; San Feliú et al., 1976) and Italy (Lumare, 1979). However, given the low growth rate of this species, when compared to the Asian Penaeus japonicus, the interest in its rearing potential decreased.

When trying to produce a species, the supply of high quality seed (either natural or artificially produced), the control of pathogenic agents and of some zootechnical parameters, as well as a good quality diet, are not sufficient. It is also necessary to develop an optimal feeding regime. Some of the problems which occur when cultivating a species, especially during the larval stages, are not only related with a poor nutritional or energetic value of the diet, but also with sub-optimal feeding regimes

\section{INTRODUCCIÓN}

Portugal tiene una importante tradición en cuanto al consumo de crustáceos. La industria pesquera es productiva, pero aún no lo suficiente como para satisfacer la demanda como, por ejemplo, en el caso del camaron cuyas descargas aún son mucho menores que los volúmenes que de él se importan. El cultivo del camarón penéido Penaeus japonicus Bate, 1888 , en sistemas intensivos y semi-intensivos en la costa sur de Portugal tuvo un crecimiento importante durante la década de los ochenta (Arrobas, 1989; Arrobas et al., 1989). Para ello, en Portugal (Figueiredo, 1970), España (Rodríguez, 1975; San Feliú et al., 1976) e Italia (Lumare, 1979) se estudió antes el potencial de cultivo de la especie autóctona Penaeus kerathurus. Sin embargo, debido a las bajas tasas de crecimiento de esta especie, en comparación con las de la especie asiática Penaeus japonicus, el interés en su potencial disminuyó.

El abastecimiento de semilla de alta calidad (producida ya sea de forma natural o artificial), el control de agentes patógenos y de algunos parámetros zootécnicos, así como una dieta de buena calidad, no son suficientes cuando se trata de cultivar una especie. También es necesario desarrollar una dieta balanceada óptima. Algunos de los problemas que ocurren cuando 
(Cuenca and Gallego, 1987). For this reason, it is very important to study the feeding behaviour of the animal in culture. The ingestion rate, defined by Paffenhöfer (1971) as the amount of food ingested per larva per unit of time, has been used as a way to quantify the larval behavioural response towards food (LoyaJavellana, 1989), which may help identifying the ideal feeding regime.

Marine crustaceans are characterised by a complex larval development. Important physiological and morphological changes occur together with modifications in their feeding behaviour, from non-selective filter-feeders (herbivorous) to active predators (carnivores) (Lovett and Felder, 1990; Lavens et al., 1995). The Penaeidae exhibit one of the most complex feeding behaviour patterns within the Decapoda. They start by the nauplii stage, with endotrophy, then develop to the protozoea and finally to the mysis stage. Little is known about their natural diet but most commercial farms use microalgae to feed the protozoea and Artemia nauplii to feed the mysis. Palaemon serratus is characterised by a more advanced development at hatching, lacking the nauplii stage, and they are fed zooplankton prey at first feeding.

Having this in mind, the aim of the present work was to study some aspects of larval feeding behaviour of two autochthonous species of shrimp, Penaeus kerathurus and Palaemon serratus. For $P$. kerathurus, feeding rates using two microalgae (Chlorella sp. and Isochrysis galbana), at 3 different concentrations, during the protozoea stage and Artemia franciscana at 4 different densities, during the mysis stage, were determined. The selectivity between Brachionus plicatilis organisms and $A$. franciscana nauplii was also tested during this stage. In the case of Palaemon serratus, the selectivity and feeding rates were determined, using three different live diets based on $A$. franciscana. se cultiva una especie, principalmente durante sus estadios larvales, no solo se relacionan con un bajo valor nutrimental o energético de la dieta, sino también con regímenes dietéticos por debajo del óptimo (Cuenca y Gallego, 1987). Por esta razón, es muy importante estudiar el comportamiento alimenticio de la especie en cultivo. La tasa de ingestión, definida por Paffenhöfer (1971) como la cantidad de comida consumida por larva, por unidad de tiempo, ha sido utilizada como una forma de cuantificar el comportamiento de la larva hacia la comida (Loya-Javellana, 1989), lo cual puede ayudar a identificar el régimen alimenticio ideal.

Los crustáceos marinos se caracterizan por un desarrollo larvario complejo. Cambios fisiológicos y morfológicos importantes ocurren junto con modificaciones en su comportamiento alimenticio, ya que se convierten de animales filtradores no selectivos (herbívoros) a depredadores activos (carnívoros) (Lovett y Felder, 1990; Lavens et al., 1995). Los Penéidos ostentan uno de los patrones de comportamiento alimenticio más complejos dentro de los decápodos. Inician en el estadio nauplio con endotrofía, después se desarrollan en protozoeas $\mathrm{y}$, finalmente, al estadio misis. Se conoce muy poco acerca de su dieta natural, pero la mayoría de las granjas comerciales utilizan microalgas para alimentar a las protozoeas y nauplios de Artemia para alimentar a las misis. Palaemon serratus se caracteriza por un desarrollo más avanzado al momento de eclosionar, ya que carece del estadio nauplio y se alimenta de presas zooplánctonicas ya en su primera ingesta.

Teniendo esto en mente, el objetivo del presente trabajo fue estudiar algunos aspectos del comportamiento alimenticio de las larvas de dos especies autóctonas de camarón, Penaeus kerathurus y Palaemon serratus. Las tasas de alimentación para $P$. kerathurus se determinaron utilizando dos microalgas 
Ciencias Marinas, Vol. 27, No. 4, 2001

\section{MATERIALS AND METHODS}

Larvae were obtained from wild Penaeus kerathurus females collected from the Sado River estuary (Portugal) and from Palaemon serratus females collected at the Tagus River estuary (Portugal). P. kerathurus stage IV (mature), V-2 and V-3 (partially spawned) females were selected according to Primavera (1985) and transferred to 4- $\mathrm{m}^{3}$ tanks filled with 2000 litres of seawater with a salinity of $35 \%$ and gentle bottom aeration. Spawning was induced through a progressive thermal shock (from $20^{\circ} \mathrm{C}$ to $26^{\circ} \mathrm{C}$ in 12 hours). Females were kept in the dark during the entire incubation period (around 48 hours). Palaemon serratus larvae hatched naturally in a 240 litre tank with untreated recirculating seawater, at $23^{\circ} \mathrm{C}$ and $25 \%$, and were collected in a removable collector with a $390-\mu \mathrm{m}$ mesh.

In $P$. kerathurus, the three protozoea and the mysis phases were used, while in Palaemon serratus the experiments were performed during the stages Zoea III, V and VII. Larvae (in the tested phases) were stocked individually in small 20-ml plastic containers, with 5 replicas per treatment.

\section{Penaeus kerathurus}

For the feeding rate experiments of $P$. kerathurus, the microalgae Chlorella $\mathrm{sp}$. and Isochrysis galbana were used, at 25, 50 and $100 \times 10^{3}$ cells $\mathrm{L}^{-1}$, during the protozoeal phases. During the mysis stage, 4 different prey densities were tested: 2, 5, 10 and $20 \mathrm{~A}$. franciscana nauplii $\mathrm{mL}^{-1}$. The selectivity between $B$. plicatilis and $A$. franciscana nauplii was determined at the mysis stage. Rotifers were always supplied at twice the amount of Artemia nauplii, i.e., 4, 10, 20 and 40 Brachionus $\mathrm{mL}^{-1}$.
(Chlorella sp. e Isochrysis galbana) a 3 concentraciones distintas, durante el estadio Protozoea, y A. franciscana a 4 diferentes desnidades, durante el estadio misis. En esta fase también se evaluó la selectividad entre organismos de Brachionus plicatilis y nauplios de A. Franciscana. En el caso de Palaemon serratus, la selectividad y las tasas de alimentación fueron determinadas utilizando tres diferentes dietas basadas en $A$. franciscana viva.

\section{MATERIALES Y MÉTODOS}

Las larvas fueron obtenidas a partir de hembras de Penaeus kerathurus silvestres, recolectadas del estuario del Río Sado (Portugal) y a partir de hembras de Palaemon serratus, también silvestres, procedentes del estuario del Río Tajo (Portugal). Las hembras de $P$. kerathurus en los estadios IV (maduras), $\mathrm{V}-2$ y V-3 (parcialmente desovadas) fueron seleccionadas de acuerdo a Primavera (1985) y transferidas a tanques de $4 \mathrm{~m}^{3}$ conteniendo 2000 litros de agua de mar, con 35\%o de salinidad y aireación suave en el fondo. El desove fue inducido mediante un choque térmico progresivo (de $20^{\circ} \mathrm{C}$ a $26^{\circ} \mathrm{C}$ en 12 horas). Las hembras fueron mantenidas en la oscuridad durante todo el periodo de incubación (cerca de 48 horas). Las larvas de Palaemon serratus eclosionaron de forma natural en un tanque de 240 litros con agua de mar sin tratamiento y con circulación a $23^{\circ} \mathrm{C}$ y $25 \%$ y posteriormente fueron recolectadas mediante un colector removible con una malla de $390 \mu \mathrm{m}$ de luz.

Para P. kerathurus se utilizaron los tres estadios protozoea y el estadio misis, mientras que con Palaemon serratus los experimentos se realizaron durante los estadios Zoea III, V y VII. Las larvas (en los estadios de prueba) fueron almacenadas individualmente en contenedores pequeños de plástico de $20 \mathrm{ml}$, con 5 réplicas por tratamiento. 
The selectivity was studied according to the index proposed by Ivlev (1955, cited by Yúfera et al., 1984), which is calculated as:

$$
\text { Selectivity }=(r-p) /(r+p) \text {, }
$$

where $\mathbf{r}$ is the percent consumption of an organism and $\mathbf{p}$ the percent of occurrence of that organism in the culture medium. The results can vary between +1 and -1 and thus the selectivity may be positive or negative.

Larval feeding on microalgae was checked every $15 \mathrm{~min}$ (up to a maximum of $90 \mathrm{~min}$ ) and the feeding rate was established as the period of time needed to fill the larval gut. When larvae were feeding on zooplankton, feeding rates were calculated by counting the number of live preys in the culture container after 24 hours.

Microalgae were used only in the exponential phase. They were removed from 80-litre plastic bags and their concentration was determined through a Bürker counting chamber. Afterwards, they were diluted to attain the experimental concentrations. A. franciscana (GSL) cysts were decapsulated (Van Stappen, 1996), incubated and the newly hatched nauplii were washed and concentrated. B. plicatilis were maintained in 180-litre tanks and were fed Chlorella sp., supplemented with baker's yeast. $B$. plicatilis and A. franciscana concentrations were calculated by counting 5 filtered and washed micropipette aliquots. Afterwards, a volume was transferred to the larval culture medium, in order to achieve the experimental densities.

Larvae were kept at $25^{\circ} \mathrm{C}$ and $30 \%$ of salinity, with continuous illumination of over 1500 lux and without aeration.

\section{Palaemon serratus}

Daily feeding rates of Palaemon serratus were determined during stages Zoea III, V and

\section{Penaeus kerathurus}

Para los experimentos de la tasa de alimentación de $P$. kerathurus se utilizaron las microalgas Chlorella sp. e Isochrysis galbana con concentraciones de 25,50 y $100 \times 10^{3}$ células $\mathrm{L}^{-1}$ durante los estadios de protozoea. Durante la etapa misis, se utilizaron cuatro densidades diferentes de presas: 2, 5, 10 y 20 nauplios de $A$. franciscana por $\mathrm{mL}$. La selectividad entre $B$. Plicatilis y los nauplios de A. franciscana se determinó en el estadio misis. Los rotíferos siempre fueron suministrados al doble de los nauplios de $A$. franciscana, v.g., 4, 10, 20 y 40 Brachionus $\mathrm{mL}^{-1}$.

La selectividad fue estudiada mediante el índice propuesto por Ivlev (1955, citado por Yúfera et al., 1984), el cual se calcula de la siguiente manera:

$$
\text { Selectividad }=(r-p) /(r+p),
$$

donde $\mathbf{r}$ es el porcentaje de consumo de un organismo y $\mathbf{p}$ el porcentaje de ocurrencia de ese organismo en el medio de cultivo. Los resultados pueden variar entre $+1 \mathrm{y}-1$, por lo que la selectividad puede ser positiva o negativa.

La alimentación de las larvas con microalgas fue comprobada cada 15 min (hasta un máximo de $90 \mathrm{~min}$ ) y la tasa de alimentación fue establecida como el periodo de tiempo requerido para llenar el intestino de la larva. Cuando las larvas fueron alimentadas con zooplancton, las tasas de alimentación se calcularon contando el número de presas vivas en el tanque de cultivo después de 24 horas.

Las microalgas se utilizaron sólo en la fase exponencial, extrayéndolas de bolsas de plástico de 80 litros y su concentración fue determinada mediante una cámara de conteo Bürker. Posteriormente, se diluyeron hasta alcanzar las 
VII. The consumption of newly hatched $A$. franciscana nauplii, metanauplii enriched during 24 hours in Protein Selco ${ }^{\circledR}$ and starved metanauplii (24 hours in seawater) was tested. A density of 5 prey $\mathrm{mL}^{-1}$ and 5 replicates per treatment were used.

Selectivity was studied using a single prey density (5 A. franciscana nauplii and $20 \mathrm{~B}$. plicatilis, per $\mathrm{mL}$ ) and a microalgae (Isochrysis galbana) concentration of $50 \times 10^{6}$ cells $\mathrm{mL}^{-1}$. The selectivity index was calculated in two larval phases, Zoea III and V.

During the experiments, larvae were maintained at $25^{\circ} \mathrm{C}$, salinity of $25 \%$, with continuous 750-lux illumination and without aeration.

Differences in ingestion rates were analysed through a one-way ANOVA and, whenever significance was accepted at $P<0.05$, the Scheffé multiple comparison test was performed (Zar, 1996).

\section{RESULTS}

\section{Penaeus kerathurus}

In all phases of the protozoea stage the feeding rates on microalgae were similar for both species tested, Chlorella sp. and Isochrysis galbana. The results revealed an inverse relationship between the microalgae concentration and the period of time needed to fill the larval gut. For a concentration of $100 \times$

$10^{3}$ cells $\mathrm{mL}^{-1}, 30$ minutes were needed for the larvae to fill their guts, while for $50 \times 10^{3}$ and $25 \times 10^{3}$ cells $\mathrm{mL}^{-1}$, it took them 45 and 90 minutes, respectively.

The results concerning the ingestion rates of $A$. franciscana nauplii at different concentrations are shown in figure 1 . There were significant differences $(P<0.05)$ among the ingestion rates of the 3 mysis phases and a clear influence of prey density in the larval feeding rate concentraciones experimentales. Los quistes de A. franciscana (GSL) fueron decapsulados (Van Stappen, 1996), incubados y los nauplios recién eclosionados se lavaron y concentraron. Los organismos de $B$. plicatilis se mantuvieron en tanques de 180 litros y se alimentaron con Chlorella sp. y un suplemento de levadura para hornear. Las concentraciones de B. Plicatilis y A. franciscana fueron calculadas contando 5 alícuotas tomadas con micropipeta, filtradas y lavadas. Posteriormente, un volumen de estas se transfirió al medio de cultivo de las larvas hasta alcanzar las densidades experimentales.

Las larvas fueron mantenidas a $25^{\circ} \mathrm{C}$ y a una salinidad de $30 \%$ con iluminación continua de 1500 lux y sin aireación.

\section{Palaemon serratus}

Las tasas de alimentación diarias de Palaemon serratus fueron determinadas durante los estadios Zoea III, V y VII. Se probaron el consumo de nauplios recién eclosionados de $A$. franciscana, el de metanauplios enriquecidos durante 24 horas con Protein Selco ${ }^{\circledR}$ y el de metanauplios sin alimentar (mantenidos por 24 horas en agua de mar). Se utilizaron una densidad de 5 presas por $\mathrm{mL}$ y 5 réplicas por tratamiento.

La selectividad fue estudiada con una sola densidad de presas (5 nauplios de $A$. franciscana y $20 \mathrm{~B}$. plicatilis, por $\mathrm{mL}$ ) y una concentración de microalgas (Isochrysis galbana) de $50 \times 10^{6}$ células $\mathrm{mL}^{-1}$.

El índice de selectividad fue calculado en dos estadios larvales, Zoea III y V.

Durante los experimentos, las larvas se mantuvieron a $25^{\circ} \mathrm{C}$, a $25 \%$ de salinidad, con iluminación constante de 750 lux y sin aireación.

Las diferencias en las tasas de ingestión fueron analizadas mediante un ANOVA de una 


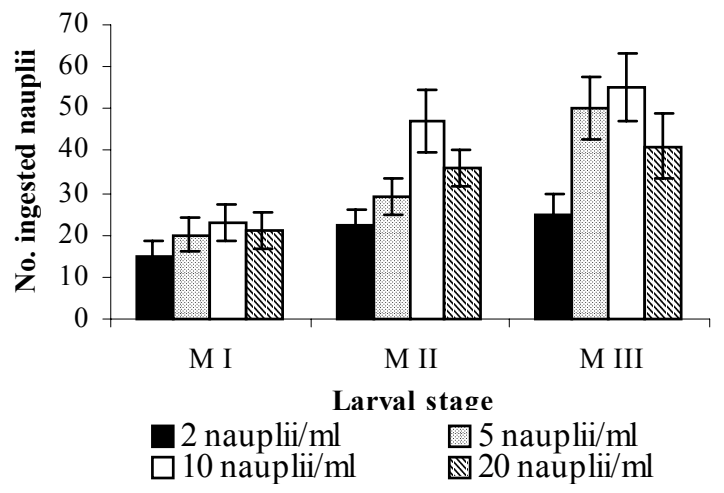

Figure 1. Penaeus kerathurus ingestion rates on Artemia franciscana nauplii at different concentrations during the mysis (M) larval stage. Results are means $(n=5) \pm$ S.D.

Figura 1. Tasas de ingestión de Penaeus kerathurus durante el estadio larval misis (M), alimentado con nauplios de Artemia franciscana a distintas concentraciones. Los resultados son promedios $(n=5) \pm$ S.D.

was found. During the mysis stage, except for Mysis I in which there were no significant differences, the optimal $A$. franciscana density was 10 nauplii $\mathrm{mL}^{-1}$. In the Mysis III phase, 2 nauplii $\mathrm{mL}^{-1}$ proved insufficient and 20 nauplii $\mathrm{mL}^{-1}$ was clearly excessive, inducing a lower ingestion than in the 5 -nauplii $\mathrm{mL}^{-1}$ density.

The Ivlev selectivity index results are shown in table 1. Figure 2 represents the $P$. kerathurus mysis feeding rate on $B$. plicatilis and $A$. franciscana, at different densities. As can be observed from table 1 and figure 2, $B$. plicatilis has a negative selectivity, while the selectivity index is always positive for $A$. franciscana nauplii. Furthermore, contrary to $B$. plicatilis, the selectivity for $A$. franciscana increased steadily during larval development. During the Mysis I phase, larvae also feed on B. plicatilis but from Mysis II onwards, there was an obvious preference for $A$. franciscana.

\section{Palaemon serratus}

The ingestion rates of Zoea III, V and VII fed on newly hatched A. franciscana nauplii, on metanauplii enriched during 24 hours in vía y siempre que éstas fueron reconocidas, utilizando un nivel de significancia de $P<0.05$, se realizó la prueba de comparaciones múltiples de Scheffé (Zar, 1996).

\section{RESULTADOS}

\section{Penaeus kerathurus}

En todas las fases del estadio de protozoea, las tasas de alimentación con microalgas fueron similares para las dos especies probadas, Chlorella sp. e Isochrysis galbana. Los resultados revelaron una relación inversa entre la concentración de microalgas y el tiempo requerido para llenar el intestino de la larva. Para una concentración de $100 \times 10^{3}$ células $\mathrm{mL}^{-1}$, se requirieron 30 minutos para que las larvas llenaran su tracto digestivo, mientras que para 50 y $25 \times 10^{3}$ células $\mathrm{mL}^{-1}$, se requirieron 45 y 90 minutos, respectivamente.

Los resultados relacionados con las tasas de ingestión de nauplios de $A$. franciscana a distintas concentraciones se muestran en la figura 1. Se encontraron diferencias significativas $(P<0.05)$ entre las tasas de alimentación de los 3 estadios misis y una clara influencia de la 
Table 1. Ivlev selectivity index for Penaeus kerathurus mysis feeding on Brachionus plicatilis and Artemia franciscana nauplii, at different concentration combinations.

Tabla 1. Índice de selectividad de Ivlev para larvas misis de Penaeus kerathurus alimentadas con Brachionus plicatilis y nauplios de Artemia franciscana, a diferentes combinaciones de concentración..

\begin{tabular}{|c|c|c|c|c|}
\hline \multirow{2}{*}{$\begin{array}{l}\text { Larval } \\
\text { stages }\end{array}$} & \multicolumn{2}{|c|}{2 Artemia/4 B.plicatilis $/ \mathrm{mL}$} & \multicolumn{2}{|c|}{5 Artemia/10 B.plicatilis/mL } \\
\hline & Artemia & B. plicatilis & Artemia & B. plicatilis \\
\hline Mysis I & 0.28 & -0.22 & 0.28 & -0.23 \\
\hline Mysis II & 0.28 & -0.23 & 0.34 & -0.48 \\
\hline Mysis III & 0.44 & -0.59 & 0.45 & -0.65 \\
\hline \multirow{2}{*}{$\begin{array}{l}\text { Larval } \\
\text { stages }\end{array}$} & \multicolumn{2}{|c|}{10 Artemia/20 B.plicatilis/mL } & \multicolumn{2}{|c|}{20 Artemia/40 B.plicatilis $/ \mathrm{mL}$} \\
\hline & Artemia & B. plicatilis & Artemia & B. plicatilis \\
\hline Mysis I & 0.25 & -0.19 & 0.37 & -0.40 \\
\hline Mysis II & 0.41 & -0.50 & 0.39 & -0.45 \\
\hline Mysis III & 0.42 & -0.54 & 0.45 & -0.65 \\
\hline
\end{tabular}

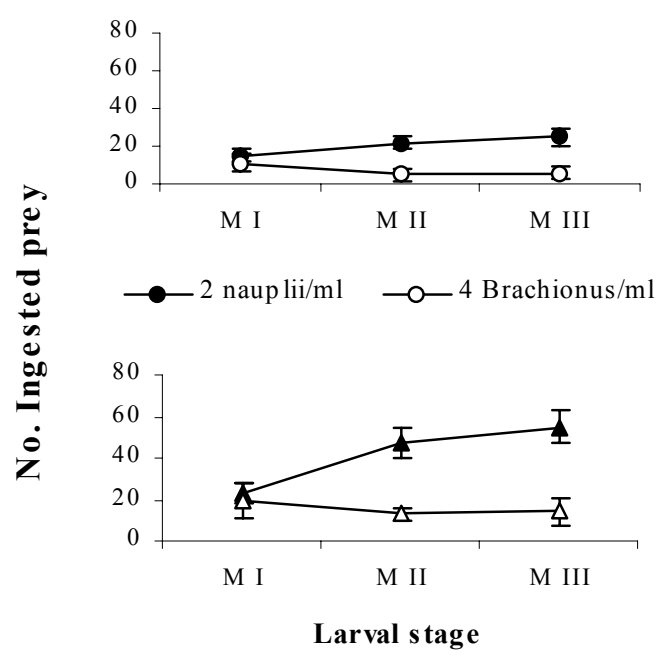

$\neg-10$ naup lii $/ \mathrm{ml} \longrightarrow-20$ Brachionus $/ \mathrm{ml}$
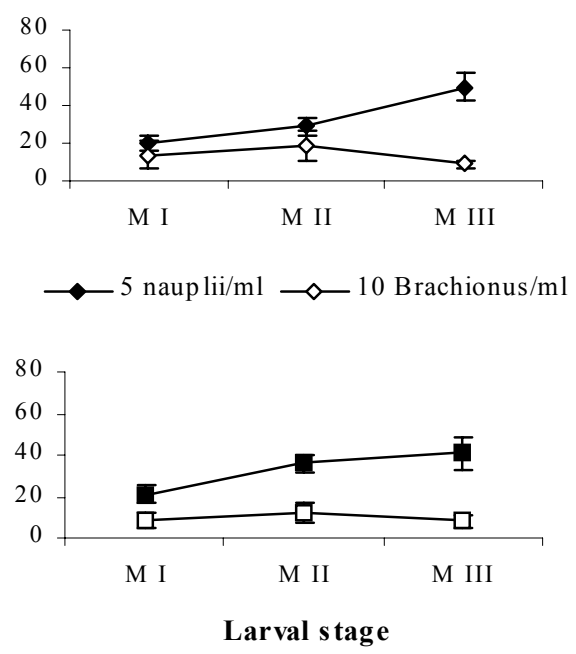

-20 naup lii $/ \mathrm{ml} \longrightarrow$ - 40 Brachionus $/ \mathrm{ml}$

Figure 2. Penaeus kerathurus ingestion rates on Brachionus plicatilis and Artemia franciscana nauplii at different concentration combinations, during the mysis $(\mathrm{M})$ larval stage.

Figura 2. Tasas de ingestión de Penaeus kerathurus durante el estadio larval misis (M), alimentados con Brachionus plicatilis y nauplios de Artemia franciscana a distintas combinaciones de concentración . 
Protein Selco ${ }^{\circledR}$ and on starved metanauplii, are shown in figure 3 . The results seem to indicate an influence of the nutritional quality of the diet in the larval feeding rate. Significant differences $(P<0.05)$ were found in the ingestion rate of the three tested diets, during Zoea III and VII. During these phases, larvae feeding on A. franciscana nauplii ingested a greater number of prey, followed by those fed on the starved metanauplii. On the other hand, larvae feeding on metanauplii enriched with Protein Selco ${ }^{\circledR}$, had a significantly lower ingestion rate. Significant differences $(P<0.05)$ were also found in the number of prey ingested by each larval phase, regardless of the diet. As expected, the results show clearly that, as larvae grow, they need to ingest a greater number of prey.

Figure 4 represents the Ivlev selectivity index and the ingestion of $A$. franciscana and $B$. plicatilis by Palaemon serratus Zoea III and V. The results show a very positive selectivity for $A$. franciscana nauplii that increases along with larval development. For B. plicatilis, on the contrary, there is a negative selectivity that decreases with development.

\section{DISCUSSION}

One of the big challenges that aquaculturists face is to determine the most suitable food organisms and the optimal density at which they should be presented to the larvae in culture. The knowledge of the optimum density of a particular food item, at each developmental stage, may avoid problems of food waste, underfeeding or water fouling (Loya-Javellana, 1989). In crustaceans this is a particularly difficult task, given the diverse developmental stages of these organisms and their different feeding preferences.

During the protozoea stage, Penaeus kerathurus feeds on microalgae. Previous densidad de las presas en las tasas de alimentación de las larvas. Durante los estadios misis, a excepción de Misis I en el que no se encontraron diferencias significativas, la densidad óptima de $A$. franciscana fue de 10 nauplios $\mathrm{mL}^{-1}$. En el estadio Misis III, 2 nauplios $\mathrm{mL}^{-1}$ fueron insuficientes y 20 nauplios $\mathrm{mL}^{-1}$ resultaron evidentemente excesivos, induciendo una ingesta menor que en la densidad de 5 nauplios $\mathrm{mL}^{-1}$.

Los resultados del índice de selectividad de Ivlev se muestran en la tabla 1 . La figura 2 presenta las tasas de alimentación de las larvas misis de $P$. kerathurus sobre $B$. plicatilis y $A$. franciscana a las distintas densidades. Como se observa en la tabla 1 y la figura 2, B. Plicatilis tiene una selectividad negativa, mientras que el índice de selectividad para los nauplios de $A$. franciscana siempre es positivo. Además, en contra de lo que sucede con B. Plicatilis, la selectividad sobre $A$. franciscana se incrementó de manera constante durante el desarro1lo larvario. Durante el estadio Misis I, las larvas también se alimentaron de B. plicatilis, pero a partir de Misis II, hubo una notable preferencia por A. franciscana.

\section{Palaemon serratus}

Las tasas de ingestión de los estadios de Zoea III, V y VII, alimentados con nauplios recién eclosionados de $A$. franciscana, con metanauplios enriquecidos con Protein Selco ${ }^{\circledR}$ durante 24 horas, y con metanauplios sin alimentar se muestran en la figura 3 . Los resultados parecen indicar una influencia de la calidad nutrimental de la dieta en las tasas de alimentación de las larvas, ya que se encontraron diferencias significativas $(P<0.05)$ en las tres dietas probadas durante los estadios Zoea III y VII. Durante estos estadios, las larvas alimentadas con nauplios de $A$. franciscana ingirieron un gran número de presas, seguidas por las que 


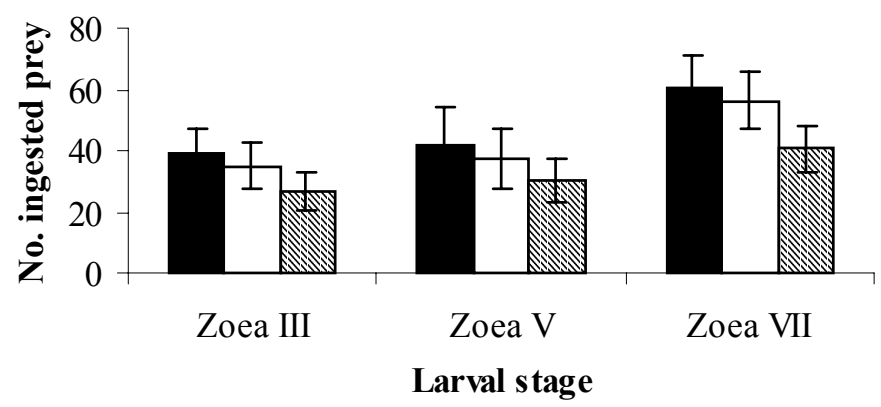

Nauplii $\square$ Starved Metanauplii $\mathbb{Q}$ P.Selco Metanauplii

Figure 3. Palaemon serratus ingestion rates on newly hatched Artemia nauplii, starved Artemia metanauplii and Artemia metanauplii enriched during $24 \mathrm{~h}$ with Protein Selco ${ }^{\circledR}$, during the Zoea III, V and VII larval stages. Results are means $(n=5) \pm$ S.D.

Figura 3. Tasas de ingestión de Palaemon serratus durante los estadios Zoea III, V y VII, alimentados con nauplios recién eclosionados de Artemia, metanauplios de Artemia sin alimentar y metanauplios enriquecidos por $24 \mathrm{~h}$ con Protein Selco ${ }^{\circledR}$. Los resultados son promedios $(n=5) \pm$ D.S.

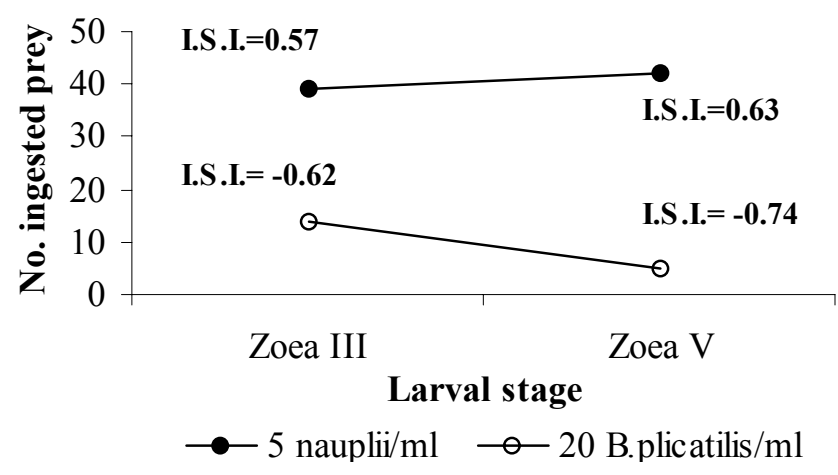

Figure 4. Palaemon serratus ingestion rates on Brachionus plicatilis and Artemia nauplii during the Zoea III and V stages. The Ivlev selectivity index (I.S.I.) is also shown for each prey item and larval stage.

Figura 4. Tasas de ingestión de Palaemon serratus durante los estadios de Zoea III y V, alimentados con Brachionus plicatilis y nauplios de Artemia. También se muestra el índice de selectividad de Ivlev (I.S.I.), para cada presa y estadio larval. 
studies conducted with Penaeus monodon fed with Chaetoceros calcitrans and Tetraselmis chuii (Tobias-Quinitio and Villegas, 1982) have shown that cell size may affect larval ingestion rate. In our study, no differences were found in the feeding rates on Chlorella sp. and Isochrysis galbana. For both species there was an inverse relationship between the microalgae concentration and the feeding rate. However, the method used to estimate the feeding rate with microalgae was very inaccurate and the results should be regarded only as reference. Wong et al. (1989) also used the period of time needed to fill the larval gut, at different algal concentrations as a way of studying ingestion rates. They found in Penaeus indicus protozoeae I feeding on Chaetoceros gracilis, a gut-filling time of 60 minutes for algal concentrations of 2 and $4 \times 10^{5}$ cells $\mathrm{mL}^{-1}$ and over 60 minutes for $1 \times 10^{5}$ cells $\mathrm{mL}^{-1}$.

The results demonstrate that the ingestion rate of $P$. kerathurus mysis is influenced by the prey density. The relationship between the food density and the larval ingestion rate has been found to be linear in Penaeus marginatus (Gopalakrishnan, 1976) and Penaeus setiferus (Rosas et al., 1995), and asymptotic in other decapod species, such as Penaeus indicus (Emmerson, 1980), Penaeus monodon (LoyaJavellana, 1989), Palaemon serratus (Yúfera and Rodriguez, 1985), Metapenaeus ensis (Chu and Shing, 1986), Ranina ranina (Minagawa and Murano, 1993) and Lysmata wurdemanni (Zhang et al., 1998). In the present study, the ingestion rate increased with increasing food concentration, but there was a saturation level (> 10 nauplii $\mathrm{mL}^{-1}$ ), above which a further increase in food density does not yield a corresponding increase in the ingestion rate. Yúfera et al. (1984) found a slightly higher saturation level (15-18 nauplii $\left.\mathrm{mL}^{-1}\right)$ than that found in the present work. se alimentaron con metanauplios sin alimentar. Por otro lado, Las larvas que se alimentaron con metanauplios enriquecidos con Protein Selco ${ }^{\circledR}$, tuvieron una tasa de ingestión significativamente menor. También se encontraron diferencias significativas $(P<0.05)$ en el número de presas ingeridas por cada estadio larval, independientemente de la dieta. Como se esperaba, los resultados muestran claramente que, al crecer las larvas, éstas necesitan ingerir mayor número de presas.

La figura 4 representa el índice de selectividad de Ivlev y la ingestión de $A$. franciscana y B. plicatilis por Zoea III y V de Palaemon serratus. Los resultados muestran una selectividad positiva sobre los nauplios de $A$. franciscana que se incrementa conforme la larva se desarrolla. Por el contrario, en el caso de $B$. plicatilis, hay una selectividad negativa que disminuye con el desarrollo.

\section{DISCUSIÓN}

Uno de los grandes retos que enfrenta la acuacultura es el determinar el organismo más apropiado y la densidad óptima en la que éste debe presentarse a la larva en proceso de cultivo. El conocimiento de la densidad óptima de un alimento en particular, en cada estadio de desarrollo, puede evitar problemas de desperdicio de alimento, mala alimentación o mala calidad del agua (Loya-Javellana, 1989). Con los crustáceos, ésta es una labor particularmente difícil, dados los diversos estadios larvales que presentan estos organismos y sus distintas preferencias alimenticias.

Durante el estadio Protozoea, Penaeus kerathurus se alimenta de microalgas. Estudios previos con Penaeus monodon alimentado con Chaetoceros calcitrans y Tetraselmis chuii (Tobias-Quinitio y Villegas, 1982) han demostrado que el tamaño de la célula puede afectar la tasa de ingestión de la larva. En el presente estudio, no se encontraron diferencias en las 
The best prey density for the culture of $P$. kerathurus mysis seems to be around $10 \mathrm{~A}$. franciscana nauplii $\mathrm{mL}^{-1}$, which resulted in an ingestion of 47 nauplii day $^{-1}$ in the Mysis I phase and 55 nauplii day ${ }^{-1}$ in the Mysis II phase. These numbers agree with data from Yúfera et al. (1984), who found ingestion rates of 48-62 nauplii day ${ }^{-1}$ in $P$. kerathurus mysis II and III, and 77-100 nauplii day ${ }^{-1}$ in post-larvae. Other authors (Shigueno, 1975, cited by Yúfera et al., 1984) obtained ingestion rates of 45 nauplii day $^{-1}$ for $P$. japonicus Mysis III to PL2 stages and 85 nauplii day ${ }^{-1}$ for PL 2-4. Many different feeding rates have been found by different authors, for other species. Studies by Gopalakrishnan (1976) revealed feeding rates of 110-200 nauplii day ${ }^{-1}$ in P. marginatus mysis while Emmerson (1984) worked with P.indicus and obtained results of 56-113 nauplii day ${ }^{-1}$ during the Mysis II phase and 165-260 nauplii day ${ }^{-1}$ during Mysis III. For Metapenaeus ensis, ingestion rates of 10 nauplii day $^{-1}$ were calculated for Mysis III (Chu and Shing, 1986). Wilkenfeld et al. (1981, 1984) suggest that the optimal Artemia sp. density for $P$. aztecus, $P$. setiferus and $P$. vannamei is 3 nauplii $\mathrm{mL}^{-1}$ which, in the present study, is apparently insufficient for $P$. kerathurus. The same optimal prey density (3 Artemia nauplii $\mathrm{mL}^{-1}$ ) was found for Lysmata wurdemanni Zoea (Zhang et al., 1998), while Gallardo et al. (1995) and Rosas et al. (1995) recommended an Artemia concentration of 1 nauplii $\mathrm{mL}^{-1}$ for Penaeus setiferus mysis culture.

During the larval stages of predatory decapods, capture of food particles results from chance encounter, with mechanoreceptors being involved in this process. Ingestion, on the other hand, is determined by chemical stimulus (Kurmaly et al., 1989, 1990). It is therefore odd tasas de alimentación con Chlorella sp. e Isochrysis galbana. Para ambas especies, se encontró una relación inversa entre la concentración de microalgas y la tasa de alimentación. Sin embargo, el método utilizado para estimar la tasa de alimentación con microalgas fue poco preciso y los resultados deben ser considerados tan solo como referencia. Wong et al., (1989) también utilizaron el tiempo necesario para llenar el intestino de la larva, usando distintas concentraciones como una forma de estudiar las tasas de ingestión. Ellos encontraron que la Protozoea I de Penaeus indicus, alimentada con Chaetoceros gracilis, requería de 60 minutos en concentraciones de 2 y $4 \times 10^{5}$ células $\mathrm{mL}^{-1}$ para llenar su tracto digetivo y de más de 60 minutos, en una concentración de $1 \times 10^{5}$ células $\mathrm{mL}^{-1}$.

Los resultados demuestran que la tasa de ingestión en misis de $P$. kerathurus está influenciada por la densidad de la presa. Se han encontrado distintos tipos de relación entre la densidad de la presa y la tasa de alimentación. Esta ha sido lineal en las larvas de Penaeus marginatus (Gopalakrishnan, 1976) y Penaeus setiferus (Rosas et al., 1995), y asintótica en otras especies de decápodos como Penaeus indicus (Emmerson, 1980), Penaeus monodon (Loya-Javellana, 1989), Palaemon serratus (Yúfera y Rodríguez, 1985), Metapenaeus ensis (Chu y Shing, 1986), Ranina ranina (Minagawa y Murano, 1993) y Lysmata wurdemanni (Zhang et al., 1998). En el presente estudio, la tasa de ingestión se incrementó con la concentración del alimento, pero se encontró un nivel de saturación ( $>10$ nauplios $\mathrm{mL}^{-1}$ ) sobre el que un incremento en la densidad del alimento no conduce al aumento correspondiente en la tasa de ingestión. Yúfera et al. (1984) encontraron un nivel de saturación ligeramente mayor (15-18 nauplios $\mathrm{mL}^{-1}$ ) que el encontrado en este estudio. 
that larvae cultured with a prey concentration of 20 nauplii $\mathrm{mL}^{-1}$ ingested less food particles than at 10 nauplii $\mathrm{mL}^{-1}$ and even at 5 nauplii $\mathrm{mL}^{-1}$ (in the Mysis III phase). The confined culture space in which the experiment was conducted may have been responsible for these results. Culture in a confined space has been suspected to affect acceptability of artificial diets by lobster larvae (Kurmaly et al., 1990).

During P. kerathurus Mysis I there is still ingestion of $B$. plicatilis, particularly at lowrotifer concentrations (4-20 rotifers $\mathrm{mL}^{-1}$ ). Nevertheless, the Ivlev selectivity indexes revealed that the mysis phases of $P$. kerathurus have a clear preference for Artemia, when presented both $A$. franciscana and B. plicatilis. This is probably caused by a more favourable predator-prey relationship with Artemia nauplii than with $B$. plicatilis due to visual stimuli, size and movement, among others. In general, decapod larvae show a low ingestion rate of small food items, with larvae being able to select food according to its size (Grahame, 1983). Moreover, more advanced developmental stages tend to prey on larger-sized food items.

As expected, larval feeding rate increased sharply with larval development, both in $P$. kerathurus and Palaemon serratus. This has been found in many other decapod species (Loya-Javellana, 1989; Minagawa and Murano, 1993; Rosas et al., 1995; Zhang et al., 1998).

An interesting result was obtained when feeding Palaemon serratus larvae with $A$. franciscana metanauplii enriched with Protein Selco ${ }^{\circledR}$. This commercial enrichment product increases dramatically the lipid content of the prey (Narciso et al., 1999), giving them a higher lipid nutritional quality. However, the ingestion rate of the enriched prey was lower than the ingestion rate of starved metanauplii and newly hatched nauplii. This could probably be explained by the increase in the energetic
La mejor densidad de presas para el cultivo de misis de $P$. kerathurus parece ser alrededor de 10 nauplios de $A$. franciscana por $\mathrm{mL}$, el cual resulta en una ingesta de 47 nauplios día ${ }^{-1}$ en el estadio Misis I y, de 55 nauplios día ${ }^{-1}$, en Misis II. Estos valores concuerdan con los datos de Yúfera et al. (1984), quienes encontraron tasas de ingestión de 48-62 nauplios día ${ }^{-1}$ en Misis II y III de P. kerathurus, y de 77-100 nauplios día ${ }^{-1}$ en sus postlarvas. Otros autores (Shigueno, 1975, citado por Yúfera et al., 1984), obtuvieron tasas de alimentación de 45 nauplios día ${ }^{-1}$ para estadios de Misis III a PL2 de $P$. japonicus y 85 nauplios día ${ }^{-1}$ para PL 2-4. Para otras especies, diversos autores han encontrado distintas tasas de alimentación. Los estudios de Gopalakrishnan (1976), revelaron tasas de alimentación de 110-200 nauplios día ${ }^{-1}$ en misis de $P$. marginatus, mientras que Emmerson (1984) trabajó con $P$. indicus y obtuvo resultados de 56-113 nauplios día ${ }^{-1}$ en Misis II y de 165-260 nauplios día ${ }^{-1}$ en Misis III. Para Metapenaeus ensis, se calcularon tasas de alimentación de 10 nauplios día ${ }^{-1}$ en misis III (Chu y Shing, 1986). Wilkenfeld et al. (1981, 1984) sugieren que la densidad óptima de Artemia sp. para P. aztecus, P. setiferus y $P$. vannamei es de 3 nauplios $\mathrm{mL}^{-1}$, densidad que en este estudio aparentemente resultó insuficiente para P. kerathurus. Zhang et al. (1998) encontraron la misma densidad óptima (3 nauplios de Artemia sp. por mL) para la Zoea de Lysmata wurdemanni, mientras que Gallardo et al. (1995) y Rosas et al. (1995) recomiendan concentraciones de Artemia de un nauplio $\mathrm{mL}^{-1}$ para el cultivo de misis de Penaeus setiferus.

Durante los estadios larvales de los decápodos depredadores, la captura de partículas de alimento resulta de que éstos las encuentren de manera fortuita mediante el uso de sus mecanoreceptores. Por otra parte, la ingestión está 
content of the prey, which leads to the capture of a lesser number of food items by the $P$. serratus larvae, in order to meet their minimum daily energetic requirements. As the amount of feed ingested by the larvae depends on their energetic demands, a diet with an excessive lipid content may inhibit or reduce larval appetite (Kanazawa et al., 1977; D’Abramo, 1989).

The ingestion rates obtained in this study for $P$. serratus were lower than those described by Yúfera and Rodriguez (1985) with the same abiotic conditions $\left(25^{\circ} \mathrm{C}\right.$ and $25 \%$ ) and prey densities, which were 48 nauplii day $^{-1}$ in Zoea III and V and 69 nauplii day ${ }^{-1}$ in the Zoea VII phase. However, these differences were probably caused by the use of different criteria for identifying each larval stage. In the present study, the larval identification criteria followed, was that from Richard (1974), Campillo (1979) and Goyanes (1987), which considers 8 larval stages. Yúfera and Rodriguez (1985), on the other hand, followed a classification that considered only 7 larval stages.

In conclusion, the results obtained in the present work suggest that the optimal Artemia franciscana density for the rearing of Penaeus kerathurus mysis is around 10 nauplii $\mathrm{mL}^{-1}$. The use of a higher prey density would be economically disadvantageous, since the excess food would not be consumed by the larvae and, eventually, would lead to a decrease in water quality. This conclusion agrees with other works on the subject (Yúfera et al., 1984).

It has also been shown that the use of enrichment products leading to a very high lipid content of the prey can cause the consumption of less food items. It would be interesting to analyse larval growth and survival, in order to assess the consequences of a reduced consumption of prey with a high-lipid content.

Finally, it has been demonstrated that shrimp larvae, either Penaeus kerathurus (at determinada por estímulos químicos (Kurmaly et al., 1989, 1990). Por lo tanto, es extraño que las larvas cultivadas con una concentración de 20 nauplios $\mathrm{mL}^{-1}$ hayan ingerido menos alimento que aquellas con concentraciones de 10 nauplios $\mathrm{mL}^{-1} \mathrm{e}$ incluso que aquellas con 5 nauplios $\mathrm{mL}^{-1}$ (en el estadio Misis III). El espacio de confinamiento en el que se desarrolló el experimento pudo ser la causa de estos resultados. Se ha sospechado que el cultivo confinado a un espacio afecte la aceptabilidad de las dietas artificiales en las larvas de langosta (Kurmaly et al., 1990).

En el estadio Misis I de P. kerathurus aún se da la ingestión de $B$. plicatilis, sobretodo a bajas concentraciones (4-20 rotíferos $\mathrm{mL}^{-1}$ ), a pesar de que los índices de selectividad de Ivlev revelaron que los estadios misis de $P$. kerathurus tienen una clara preferencia por Artemia cuando se les suministran tanto $A$. franciscana como $B$. plicatilis. Esto probablemente se debe a la relación depredador-presa más favorable con los nauplios de Artemia que con $B$. plicatilis debido al estímulo visual, al tamaño y al movimiento entre otros. En general, las larvas de decápodos muestran una tasa de ingestión baja de partículas de alimento pequeñas ya que sus larvas son capaces de seleccionar el alimento de acuerdo a su tamaño (Grahame, 1983). Además, los estadios de desarrollo más avanzados tienden a apresar partículas alimenticias más grandes.

Tal y como se esperaba, la tasa de alimentación se incrementó bruscamente con el desarrollo larvario tanto en $P$. kerathurus como en Palaemon serratus. Esto se ha encontrado en otras muchas especies de decápodos (LoyaJavellana, 1989; Minagawa y Murano, 1993; Rosas et al., 1995; Zhang et al., 1998).

Un resultado interesante se obtuvo cuando las larvas de Palaemon serratus se alimentaron con metanauplios de A. franciscana enriqueci- 
least from Mysis I onwards) or Palaemon serratus, have a negative selectivity for Brachionus plicatilis. This may be considered a major advantage, since the maintenance of the trophic chain is considered one of the most expensive and labour intensive activities of a marine hatchery. Thus, the complete or partial elimination of the trophic chain is one of the main objectives in marine aquaculture nowadays.

\section{ACKNOWLEDGEMENTS}

Sofia Morais wishes to acknowledge IMAR (Institute of Marine Research) for its financial support, through a research grant.

\section{REFERENCES}

Arrobas, I. (1989). Culture of Kuruma prawn Penaeus japonicus in Portugal. European Aquaculture Society Special Publication, 10: 15-16.

Arrobas, I., Soares, F. and Modesto, T. (1989). Producción experimental del langostino Penaeus japonicus en la Ria Formosa. In: M. Yúfera (ed.), Acuicultura Intermareal, Cádiz, pp. 335340.

Campillo, A. (1979). Contribution à l'étude de la crevette rose Palaemon serratus. Exploitation, biologie, élevage et epidemiologie. Thése Doctorat Université de Sciences et Techniques du Languedoc, Nantes, 247 pp.

Chu, K.H. and Shing, C.K. (1986). Feeding behaviour of the shrimp Metapenaeus ensis on Artemia nauplii. Aquaculture, 58: 175-184.

Cuenca, E.M. and Gallego, M. (1987). Ingesta y conducta alimentaria. In: CAICYT (ed.), Nutrición en Acuicultura, Vol. I, Madrid, pp. 165.

D'Abramo, L.R. (1989). Lipid requirements of shrimp. In: IFREMER (ed.), Actes de Colloque Advances in Tropical Aquaculture, 9, Aquacop, pp. 271-285.

Emmerson, W.D. (1980). Ingestion, growth and development of Penaeus indicus larvae as a dos con Protein Selco ${ }^{\circledR}$. Este producto de enriquecimiento comercial incrementa dramáticamente el contenido de lípidos de las presas (Narciso et al., 1999), otorgándoles una mayor calidad nutrimental de lípidos. Sin embargo, la tasa de ingestión con presas enriquecidas fue menor a la tasa de ingestión con metanauplios sin alimentar o con nauplios recién eclosionados. Es probable que el incremento en el contenido energético de la presa, conduzca a la captura de un menor número de presas por las larvas de $P$. serratus, dado que se requiere de una cantidad menor de partículas para satisfacer sus requerimientos energéticos diarios. Dado que la cantidad de alimento ingerido por la larva depende de la demanda energética, una dieta con un contenido excesivo de lípidos puede inhibir o reducir el apetito de la larva (Kanazawa et al., 1977; D’Abramo, 1989).

Las tasas de alimentación obtenidas en este estudio para $P$. serratus fueron más bajas que las descritas por Yúfera y Rodríguez (1985) en las mismas condiciones abióticas $\left(25^{\circ} \mathrm{C}\right.$ y $25 \%$ ) y con densidades de presas de 48 nauplios día ${ }^{-1}$, en Zoea III y V, y de 69 nauplios día $^{-1}$ en el estadio Zoea VII. Sin embargo, estas diferencias fueron probablemente causadas por el uso de distintos criterios para la identificación de cada estadio larval. En este estudio, se siguieron los criterios descritos por Richard (1974), Campillo (1979) y Goyanes (1987), quienes consideran 8 estadios larvales. En contraste, Yúfera y Rodríguez (1985) siguieron una clasificación que considera sólo 7 estadios larvales.

En conclusión, los resultados obtenidos en este trabajo sugieren que una densidad óptima de Artemia franciscana para las misis de Penaeus kerathurus es cercana a los 10 nauplios $\mathrm{mL}^{-1}$. El uso de una densidad mayor de presas presentaría desventajas económicas, ya que el exceso de alimento no sería consumido por las larvas y, eventualmente, conduciría a 
function of Thalassiosira weissflogii cell concentration. Marine Biology, 58: 65-73.

Emmerson, W.D. (1984). Predation and energetics of Penaeus indicus (Decapoda: Penaeidae) larvae feeding on Brachionus plicatilis and Artemia nauplii. Aquaculture, 38: 201-209.

Figueiredo, M.J. (1970). A cultura de animais marinhos, perspectivas de uma cultura artificial de crustáceos em Portugal. Boletim Informativo de Investigação em Biologia Maritima, 3: 1-11.

Gallardo, P.P., Alfonso, E., Gaxiola, G., Soto, L.A. and Rosas, C. (1995). Feeding schedule of Penaeus setiferus larvae based on diatoms (Chaetoceros ceratosporum), flagellates (Tetraselmis chuii) and Artemia nauplii. Aquaculture, 131: 239-252.

Gopalakrishnan, K. (1976). Larval rearing of red shrimp Penaeus marginatus. Aquaculture, 9: 145-154.

Goyanes, R.R. (1987). Estudio morfologico de los estadios larvarios del camarón Palaemon serratus. Investigaciones Pesqueras, 55(1): 545560.

Grahame, J. (1983). Adaptative aspects of feeding mechanisms. In: F.J. Vernberg and W.B. Vernberg (eds.), The Biology of Crustacea, Vol. 8. Academic Press, New York, U.S.A, pp. 65 107.

Kanazawa, A., Teshima, S. and Tokiwa, S. (1977). Nutritional requirements of prawn VII. Effect of dietary lipids on growth. Bulletin of the Japanese Society of Scientific Fisheries, 43: 856 $-894$.

Kurmaly, K., Jones, D.A., Yule, A.B. and East, J. (1989). Comparative analysis of the growth and survival of Penaeus monodon (Fabricius) larvae, from Protozoea 1 to Postlarva 1, on live feeds, artificial diets and on combinations of both. Aquaculture, 81: 27-45.

Kurmaly, K., Jones, D.A. and Yule, A.B. (1990). Acceptability and digestion of diets fed to larval stages of Homarus gammarus and the role of dietary conditioning behaviour. Marine Biology, 106: 181-190.

Loya-Javellana, G.N. (1989). Ingestion saturation and growth responses of Penaeus monodon larvae to food density. Aquaculture, 81: 329336.

Lavens, P., Coutteau, P. and Sorgeloos, P. (1995). Laboratory and field variation in HUFA enrichment of Artemia nauplii. European una disminución en la calidad del agua. Esta conclusión concuerda con la de otros trabajos sobre el mismo tema (Yúfera et al., 1984).

También se mostró que el uso de productos enriquecidos que ocasionan un alto contenido de lípidos en las presas puede causar un menor consumo de partículas alimenticias. Sería interesante analizar el crecimiento de las larvas y su sobrevivencia, a fin de evaluar las consecuencias de un consumo reducido de presas con un alto contenido de lípidos.

Finalmente, se ha demostrado que las larvas de camarón, ya sea de Penaeus kerathurus (al menos desde misis I en adelante) o de Palaemon serratus, tienen una selectividad negativa sobre Brachionus plicatilis. Esto puede considerarse como una ventaja importante, ya que el sostenimiento de la cadena trófica se considera una de las actividades más costosas y que implica gran cantidad de mano de obra en un criadero marino. Por esta razón, la eliminación parcial o total de la cadena trófica es uno de los objetivos principales en la acuacultura marina moderna.

\section{AGRADECIMIENTOS}

Sofia Morais agradece al IMAR (Instituto de Investigación Marina) por su apoyo financiero mediante una beca de investigación.

Traducido al español por Adrián R. López.

Aquaculture Special Publication, 24: 137-140.

Lovett, D.L. and Felder, D.L. (1990). Ontogeny of kinematics in the gut of the white shrimp Penaeus setiferus (Decapoda; Penaeidae). Journal of Crustacean Biology, 10: 53-68.

Lumare, F. (1979). Reproduction of Penaeus kerathurus using eyestalk ablation. Aquaculture, 18: 203-214.

Minagawa, M. and Murano, M. (1993). Effects of prey density on survival, feeding rate and development of Zoeas of the red frog crab 
Ranina ranina (Crustacea, Decapoda, Raninidae). Aquaculture, 113: 91-100.

Narciso, L., Pousão-Ferreira, P., Passos, A. and Luís, O. (1999). HUFA content and DHA/EPA improvements of Artemia sp. with commercial oils during different enrichment periods. Aquaculture Research, 30: 21-24.

Paffenhöfer, G.A. (1971). Grazing and ingestion rates of nauplii, copepodids and adults of the marine planktonic copepod Calanus helgolandicus. Marine Biology, 11: 286-298.

Primavera, J.H. (1985). A review of maturation and reproduction in closed-thelycum penaeids. In: SEAFDEC Aquaculture Department (ed.), Proceedings of the First International Conference on the Culture of Penaeid Shrimps, Philippines, pp. 177.

Richard, P. (1974). Contribution à l'étude du development larvaire et de l'organogénese chez Palaemon serratus et du metabolism des acides aminés libres chez cette crevette et chez Penaeus kerathurus. Thése Doctorat Université d'AixMarseille, $139 \mathrm{pp}$

Rodriguez, A. (1975). Experiencias de cria de larvas y post-larvas de langostinos Penaeus kerathurus. Publicatión Técnica Junta Estadual de Pesca, 11: 367-386.

Rosas, C., Sanchez, A., Gallardo, P., Quiroz, J., Gaxiola, G., Diaz-Iglesia, E. and Soto, L.A. (1995). Oxygen consumption and ingestion rate of Penaeus setiferus larvae fed Chaetoceros ceratosporum, Tetraselmis chuii and Artemia nauplii. Aquaculture Nutrition, 1: 13-20.

San Feliú, J.M., Munoz, F., Amat, F., Ramos, J., Peffa, J. and Sanz, A. (1976). Téchniques de la simulation de la ponte et d'élevage de larves de crustaces et de poisson. (Ponte controlée et élevage des larves d'espéces marines sélectionnées de le Méditerranée). Études
Revues du Conseil Géneral des Pêches Méditerranées, 55: 1-34.

Tobias-Quinitio, E. and Villegas, C.T. (1982). Growth, survival and macronutrient composition of Penaeus monodon Fabricius larvae fed with Chaetoceros calcitrans and Tetraselmis chuii. Aquaculture, 29: 253-260.

Van Stappen, G. (1996). Use of cysts. In: P. Lavens and P. Sorgeloos (eds.), Manual on the production and use of live food for aquaculture. FAO Fisheries Technical Paper, 361: 107-130.

Wilkenfeld, J.S., Fox, J.M. and Lawrence, A. (1981). Consumption of frozen and live Artemia by protozoea of Penaeus setiferus. Journal of the World Mariculture Society, 12(2): 250-259.

Wilkenfeld, J.S., Lawrence, A. and Kuban, F. (1984). Survival, metamorphosis and growth of penaeid shrimp larvae reared on a variety of algal and animal foods. Journal of the World Mariculture Society, 15: 31-49.

Wong, C.K., Yuen, Y.P. and Chu, K.H. (1989). Feeding rate during the larval development of the shrimp Metapenaeus ensis. Marine Behaviour Physiology, 15: 243-253.

Yúfera, M., Rodriguez, A. and Lubián, L.M. (1984). Zooplankton ingestion and feeding behaviour of Penaeus kerathurus larvae reared in the laboratory. Aquaculture, 42: 217-224.

Yúfera, M. and Rodriguez, A. (1985). Effect of prey density on feeding rates during larval rearing of Palaemon serratus Pennant (Crustacea: Palaemonidae). Aquaculture, 50: 31-38.

Zar, J.H. (1996). Biostatistical Analysis, Prentice Hall International, Upper Saddle River, N.J., 662 pp.

Zhang, D., Lin, J. and Creswell, R.L. (1998). Ingestion rate and feeding behaviour of the Peppermint Shrimp Lysmata wurdemanni on Artemia nauplii. Journal of the World Aquaculture Society, 29(1): 97-103. 